\title{
FURTHER STUDIES ON THE MOSAIC OF THE SUGARCANE VARIETY MAYAGUEZ 336
}

\section{José Adsuar ${ }^{1}$}

\section{INTRODUCTION}

In 1950, a preliminary report on a mosaic disease of the sugarcane variety of Mayagüez 336 occurring in Puerto Rico was presented (1). ${ }^{2}$ The symptoms observed consisted in the appearance of one or two elongated chlorotic streaks with irregular margins on the lower half of the younger leaves; the streaks increased in number and formed a distinct mosaic pattern of normal green islets on a yellowish background.

Our interest was immediately aroused because M. 336 is one of our best mosaic-resistant canes. We decided first to test whether the mosaic under study was transmissible to M. 336 as well as to other varieties known to be either resistant or susceptible to the sugarcane-mosaic virus. Insect transmissions were also attempted using the corn aphid, Aphis maidis Fitch.

All efforts at the time to transmit the mosaic to other sugarcane varieties either mechanically or by means of the aphid vector failed. Only M. 336 and sorghum, Holcus sorghum L., proved susceptible. The symptoms on sorghum are characterized by a mottling of the leaves very similar to that produced by the sugarcane-mosaic virus.

Although these experiments were preliminary and very limited in extent the possibility was entertained that the virus under study might be a strain of the sugarcane-mosaic virus or an altogether different virus.

Recent and more detailed studies, however, have disclosed that the socalled mosaic of the variety M. 336 is probably identical with the sugarcanemosaic virus present on the Island.

This paper presents the results of this work.

\section{MATERIALS AND METHODS}

In all cases inoculum was prepared by grinding the infected leaves in a meat grinder which had been cooled in the refrigerator. The juice was extracted from the pulp by pressing it through muslin cloth by hand. The beaker in which the juice was collected was kept jacketed with ice. All the apparatus used in the operations was sterilized. Inoculations were performed by dusting the leaves with carborundum and rubbing on the infectious liquid with a cotton swab.

Sorghum, Holcus sorghum L., was used as test plant to check the in-

${ }^{1}$ Phytopathologist, Plant Pathology Department, Agricultural Experiment Station, University of Puerto Rico, Río Piedras, P. R.

${ }^{2}$ Numbers in parentheses refer to Literature Cited, p. 21. 
fectiousness of the inoculating juices and also in the physical-property studies of the viruses. It was selected for these purposes because of its high susceptibility to both M. 336 and sugarcane-mosaic viruses and also on account of the ease with which it is grown and handled in the laboratory.

The sugarcane plants used in the transmission experiments were selected from healthy stools and planted in 6 -inch pots. The sorghum plants were raised from seed in 5-inch pots. After inoculation the plants were kept in a screened house at temperatures between $72^{\circ}$ and $95^{\circ} \mathrm{F}$.

\section{TRANSMISSION STUDIES}

The following varities were inoculated as described under Materials and Methods: B.H. 10-12, Sta. Cruz 12/4, Co. 281, P.O.J. 2878, P.R. 902, and C.P. 29-291. Each variety was inoculated with juice from an infected M. 336 plant showing characteristic symptoms. Table 1 shows the results of the transmission experiments.

Twenty-nine sorghum plants were inoculated to test the infectiousness of the virus of which 10 became infected. As will be seen from table 1, transmission of M. 336 was accomplished in all the varieties tested with the exception of P.O.J. 2878 and P.R. 902.

A parallel transmission series was carried on simultaneously with the above-mentioned varieties using the sugarcane-mosaic virus extracted from B.H. 10-12 as inoculum. The symptoms produced by M. 336 mosaic virus on the susceptible varieties were undistinguishable from those produced by the sugarcane-mosaic virus on the same varieties. When juice from B. H. 10-12 plants previously inoculated with M. 336 mosaic virus and presenting symptoms characteristic of sugarcane-mosaic virus on this variety were inoculated back to variety M. 336, symptoms typical of M. 336 mosaic developed. It was concluded that the difference in symptomatology between the two types of mosaic was a varietal expression.

TABLE 1.-Results of the transmission experiments using YM-336 mosaic virus from M. 336 as inoculum, 1951

\begin{tabular}{|c|c|c|}
\hline Date & Variety inoculated & Results 1 \\
\hline 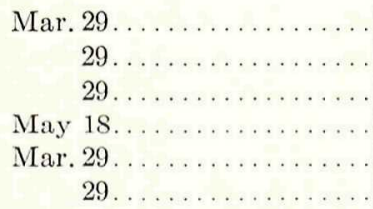 & $\begin{array}{l}\text { B.H. } 10-12 \\
\text { Sta. Cruz } 12-4 \\
\text { Co. } 281 \\
\text { C.P. } 29-291 \\
\text { P.O.J. } 2878 \\
\text { P.R. } 902\end{array}$ & $\begin{array}{l}1 / 15 \\
6 / 14 \\
4 / 14 \\
5 / 6 \\
0 / 11 \\
0 / 18\end{array}$ \\
\hline
\end{tabular}

${ }^{1}$ In this and other tables: Numerator $=$ number plants infected; denominator $=$ number plants inoculated. 


\section{STUDIES OF PHYSICAL PROPERTIES}

The results on transmission presented above led us to inquire further whether there might be differences in the physical properties of the viruses causing the mosaic of the variety M. 336 and the sugarcane-mosaic virus. To test this hypothesis M. 336 mosaic virus extracted from diseased M. 336 plants, and sugarcane-mosaic virus obtained from B.H. 10-12 were inoculated separately into healthy sorghum plants.

Sorghum was used as source of inoculum and also as a test plant in the physical-property studies for the reasons mentioned under Materials and Methods and because symptoms usually appear in less than a week and are easily observable in this plant. In addition, it has been observed that sorghum is much more susceptible than other susceptible plants, including M. 336, to the M. 336 mosaic virus under study.

Each determination was repeated at least four times, and the data presented in each case are representative of the results obtained.

\section{Resistance to Heat}

To determine the thermal death point of both viruses, 1 cc. of each mosaic juice was heated in a thin-walled test tube in a serological water bath for 10 minutes at the desired temperature after which the tubes were plunged into cold water and the inoculate was used on young sorghum seedlings.

TABLE 2.-Thermal inactivation of YM-336 and sugarcane-mosaic viruses

\begin{tabular}{c|c|c}
\hline Temperature $\left({ }^{\circ} \mathrm{C}.\right)$ & YM-336 virus & Sugarcane-mosaic virus \\
\hline$\left({ }^{1}\right)$ & $35 / 152$ & $26 / 125$ \\
$45^{\circ}$ & $9 / 66$ & $3 / 45$ \\
$50^{\circ}$ & $0 / 62$ & $0 / 38$ \\
$55^{\circ}$ & $0 / 53$ & $0 / 28$ \\
$60^{\circ}$ & $0 / 64$ & $0 / 53$
\end{tabular}

${ }^{1}$ Untreated juice.

TABLE 3.-Dilution end point of YM-336 and sugarcane-mosaic viruses

\begin{tabular}{c|c|c}
\hline Dilution & YM-336 virus & Sugarcane-mosaic virus \\
\cline { 2 - 3 }$\left({ }^{1}\right)$ & $35 / 152$ & $26 / 125$ \\
$1: 10$ & $15 / 42$ & $2 / 38$ \\
$1: 100$ & $0 / 60$ & $1 / 32$ \\
$1: 1,000$ & $0 / 44$ & $0 / 25$ \\
$1: 10,000$ & $0 / 59$ & $0 / 29$
\end{tabular}

${ }^{1}$ Undiluted juice. 
Results are presented in table 2 . It will be seen that the thermal death point of both viruses occurred at about the same temperature.

\section{Dilution End Point}

To determine the dilution end point of the viruses various dilutions of each mosaic-leaf juice were made with sterile distilled water.

Results are presented in table 3 . The results demonstrate that the dilution end point was virtually the same for both viruses.

\section{Longevity}

The longevity in vitro was determined by storing the infectious juices at room temperature $\left(28^{\circ}\right.$ to $30^{\circ} \mathrm{C}$.) for various lengths of time.

The results obtained are given in table 4 . The data indicate that the two viruses became inactivated in 24 hours at room temperature.

\section{INSECT TRANSMISSION}

Although we had been unable to transmit the M. 336 mosaic by means of the aphid vector, A. maidis Fitch, as reported in the first paper cited, trials were continued in an effort to elucidate this point. The aphids were reared on healthy corn plants grown for that purpose. The insects were collected by means of an aspirator, placed directly on the infected plants,

TABLE 4.-Longevity of YM-336 and sugarcane-mosaic viruses

\begin{tabular}{c|c|c}
\hline Time (hours) & YM-336 virus & Sugarcane-mosaic virus \\
\cline { 2 - 3 } 0 & $29 / 33$ & $14 / 23$ \\
2 & $9 / 25$ & $11 / 24$ \\
4 & $11 / 25$ & $14 / 33$ \\
6 & $4 / 17$ & $1 / 25$ \\
8 & $5 / 18$ & $4 / 34$ \\
24 & $0 / 24$ & $0 / 20$ \\
\hline
\end{tabular}

TABLE 5.-Transmission of YM-396 mosaic virus using numerous corn aphids, A. maidis Fitch, 1951

\begin{tabular}{r|c|c|c}
\hline \multicolumn{1}{c|}{ Date } & \multicolumn{1}{c|}{ Virus source } & Plant inoculate & Results \\
\cline { 2 - 3 } Mar. $19 \ldots \ldots \ldots \ldots$ & Sorghum & M. 336 & $2 / 4$ \\
$19 \ldots \ldots \ldots \ldots \ldots$ & do. & Sorghum & $2 / 48$ \\
$29 \ldots \ldots \ldots \ldots$ & do. & M. 336 & $0 / 1$ \\
Apr. $20 \ldots \ldots \ldots \ldots \ldots$ & do. & do. & $2 / 8$ \\
$24 \ldots \ldots \ldots \ldots \ldots$ & do. & do. & $1 / 3$ \\
May $18 \ldots \ldots \ldots \ldots$ & B.H. 10-12 & do. & $2 / 2$ \\
$18 \ldots \ldots \ldots \ldots$ & Sta. Cruz 12/4 & do. & $1 / 2$ \\
\hline
\end{tabular}


and permitted to feed for at least 24 hours. They were then removed by the same method and placed on the test plants.

The plants to be tested were grown from healthy seed and placed in wire-screened cages. In nearly all the trials one or two leaves of the plants to be tested were covered with cellophane bags and the infected aphids dropped in. In one case an infected sorghum plant on which aphids have been placed was put in contact with healthy plants in one of the cages. Results of the transmission experiments are given in table 5. Obviously transmission occurred in many instances.

\section{SUMMARY}

Transmission of the mosaic virus present on the sugarcane variety M. 336 is reported.

The virus was transmitted mechanically from mosaic-infected M. 336 to the varieties, B.H. 10-12, Sta. Cruz. 12/4, and C.P. 29-291. No transmissions were obtained to the varieties P.O.J. 2878 and P.R. 902, which are resistant to the sugarcane-mosaic virus.

The mosaic symptoms produced by the YM-336 virus on B.H. 10-12, Sta. Cruz 12/4, Co. 281, and C.P. 29-291 were indistinguishable from the symptoms produced on these same varieties by the sugarcane-mosaic virus.

Comparative studies were made of the physical properties of the M. 336 mosaic virus and the sugarcane-mosaic virus obtained from B. H. 10-12. No differences were observed in the properties of the two viruses. Both were inactivated at a temperature of around $45^{\circ} \mathrm{C}$., had a dilution end point of 1:10, and did not survive for more than 24 hours at room temperature.

The YM-336 virus was transmitted successfully by means of the corn aphid, A. maidis Fitch, from infected sorghum, B.H. 10-12, and Sta. Cruz $12 / 4$ to the variety M. 336 .

\section{RESUMEN}

Se informa la transmisión del virus causante del mosaico de la variedad M-336.

El virus se transmitió artificialmente por frotación del jugo de caña M-336 enferma, a caña sana de las variedades BH 10-12, Santa Cruz 12/4, Co. 281, CP 29-291. No pudo, sin embargo, transmitirse a las variedades POJ 2878 y PR 902 las cuales sabemos son resistentes al virus de la caña de azúcar.

Los síntomas producidos por el virus causante del mosaico de la caña M-336 en las variedades BH 10-12, Santa Cruz 12/4, Co. 281 y CP 29-291 son idénticos a los producidos por el virus causante del mosaico de la caña de azúcar en esas mismas variedades. 
Se verificaron estudios comparativos respecto a las propiedades físicas entre el virus del mosaico de M-336 y el de la caña de azúcar extraído de la variedad $\mathrm{BH} 10-12$. No se observaron diferencias en cuanto a dichas propiedades físicas. Ambos virus se inactivan a temperatura de $45^{\circ} \mathrm{C}$., no resisten dilución de más de 1:10 partes de agua sin inactivarse, y no sobreviven por más de 24 horas en el jugo extraído y sometido a la temperatura del laboratorio $\left(28^{\circ}-30^{\circ} \mathrm{C}\right.$.).

Se logró transmitir el virus causante del mosaico de la variedad M-336 a plantas sanas de esa misma variedad por medio del pulgón del maíz, $A$. maidis Fitch, usando como fuente de inóculo plantas de sorgo, BH 10-12 y Santa Cruz 12/4 enfermas con dicho virus.

\section{LITERATURE CITED}

1. Adsuar, José, Preliminary report of a mosaic disease of the resistant sugarcane variety Mayagüez 336, Tech. Paper No. 7 pp. 1-9, Agrl. Exp. Sta., Univ. P. R., 1950 . 